\title{
Состав, структура и свойства композитов поливиниловый спирт - природный цеолит
}

\author{
Дабижа О.Н. ${ }^{1,2}$, Хатькова А.Н. ${ }^{1}$, Рябова Н.В. ${ }^{1}$, Филенко Р.А. ${ }^{3}$ \\ ${ }^{1}$ Забайкальский государственный университет, Чита \\ ${ }^{2}$ Забайкальский институт железнодорожного транспорта, Чита \\ ${ }^{3}$ Институт природных ресурсов, экологии и криологии СО РАН, Чита
}

Поступила в редакцию 7.02.2017 г.

Синтезированы композиционные материалы «ПВС-природный цеолит» с улучшенными влагоудерживающими свойствами. Композиты изучены методами инфракрасной спектроскопии, атомноэмиссионной спектроскопии с индуктивно связанной плазмой, дифференциальной сканирующей спектроскопии и термогравиметрии. Предложены критерии для оценки адсорбционного взаимодействия ПВС и клиноптилолита - изменения относительных интенсивностей полос поглощения в ИКспектрах композитов и параметры кинетического уравнения С. Аррениуса, описывающего их дегидратацию. Подтверждено образование адсорбционных поверхностных комплексов. Определены истинная плотность, полная обменная емкость, гигроскопическая влажность образцов.

Ключевые слова: цеолиты, ПВС, механоактивация, энергия активации, полная обменная емкость, сорбенты, влажность.

\section{Composition, structure and properties of composites polyvinyl alcohol - natural zeolite}

\author{
Dabizha O.N. ${ }^{1,2}$, Khat'kova A.N. ${ }^{1}$, Ryabova N.V. ${ }^{1}$, Filenko R.A. ${ }^{3}$ \\ ${ }^{1}$ Transbaikal State University, Chita \\ ${ }^{2}$ Transbaikal Institute of Railway Transport, Chita \\ ${ }^{3}$ Institute of Natural Resources, Ecology and Cryology SB RAS, Chita
}

This article is devoted to the problem of developing inexpensive and environmentally friendly organomineral sorbents. Adsorption modification of zeolite-containing rocks of the Kholinsk and Shivyrtuy deposits with an industrial polymer - polyvinyl alcohol, was carried out in the work. Objective: to establish a connection of «composition - structure - properties» of composites based on PVA and clinoptilolite for creating sorption materials with improved properties.

Synthesis was performed by impregnating finely divided fraction of mechanically activated natural zeolite with aqueous solutions of PVA 4, 6 and $8 \mathrm{wt}$. \%. The mixture was homogenized and the solvent was removed. The formation of the surface adsorption complex confirmed by calculating the relative intensities of the absorption bands in the IR spectra, by the apparent activation energy and the pre-exponential factor in equation of S. Arrhenius, describing dehydration of samples by means curves of differential thermogravimetry. The frequencies at $3620,3440,2850-2950 \mathrm{~cm}^{-1}$ were chosen as criteria for evaluating the adsorption interaction of PVA and active surface centers of zeolites.

The density, hygroscopic humidity and total exchange capacity samples by ammonium cations were calculated. The samples with best retention of water were ХЦ-ПВС 4 (1:1) and ШЦ-ПВС $(1: 2)$. humidity.

Keywords: zeolites, polyvinyl alcohol, mechanical activation, total exchange capacity, sorbents, 


\section{Введение}

Разработка новых перспективных экологически безвредных и недорогих органоминеральных сорбентов с высокими эксплуатационными характеристиками [1] на основе местного цеолитсодержащего сырья [2] остается актуальной задачей. Перспективной наноразмерной матрицей для полимеров [3-5] являются цеолиты, характеризующиеся невысокой себестоимостью, радиационной и термической устойчивостью, экологической безопасностью. Поливиниловый спирт (ПВС) $\left[-\mathrm{CH}_{2}-\mathrm{CH}(\mathrm{OH})-\right]_{\mathrm{n}}$ представляет собой недорогой, гидрофильный, нетоксичный, стабильный, механически прочный крупнотоннажный термопластичный полимер, легко смешивающийся с наполнителями $[6,7]$. Наличие гидроксильных групп ПВС и силанольных групп клиноптилолита позволяет регулировать межфазное взаимодействие в композитах. Ранее обнаружено [8], что механоактивация клиноптилолита в виброистирателе приводит к гидратации, увеличению степени дефектности структуры и количества силанольных групп, тем самым, повышая его реакционную способность.

Цель настоящей работы: установить закономерность «состав-структурасвойства» синтезированных полимерных композитов на основе ПВС и клиноптилолита для получения сорбционных материалов с улучшенными свойствами.

\section{Эксперимент}

В качестве исходных компонентов использовали цеолитсодержащие породы крупнейших в России Холинского (ХЦ) и Шивыртуйского (ШЦ) месторождений (Забайкальский край) и ПВС марки 02-1799 производства Китай $(\eta=20-28$ мПз; $\left.\mathrm{W}_{\text {летучих веществ }}=5 \% ; \mathrm{w}_{\mathrm{CH} 3 \mathrm{COONa}}=2.5 \% ; \mathrm{pH}=5-7 ; \rho=1.19-1.31 \mathrm{r} / \mathrm{cm}^{3} ; \mathrm{t}_{\text {разложения }}=230^{\circ} \mathrm{C}\right)$.

Рентгенофазовый анализ минеральных образцов проводили методом порошка на дифрактометре ДРОН-3 на СuK ${ }_{\alpha}$-излучении $(\mathrm{U}=25$ кB, I=20 мА, угловой диапазон от 3 до $55^{\circ} 2 \theta$, скорость сканирования $1 \%$ мин, $\mathrm{Ni}$ - фильтр). Фазовый состав ХЦ, w,\%: клиноптилолит 45; стильбит 29; полевой шпат 21; кварц 5. Фазовый состав ШЦ, w,\%: клиноптилолит 52; полевой шпат 34; кварц 14. Содержание пластинчатого стильбита в образце ХЦ должно способствовать его более эффективной аморфизации при механоактивации [8].

Химический состав минеральных образцов изучен с помощью атомноабсорбционного спектрометра Perkin Elmer Analist 400 и атомно-эмиссионного спектрометра с индуктивно-связанной плазмой Perkin Elmer Optima 2100. Образцы предварительно растворяли в смеси кислот $\mathrm{HCl}, \mathrm{HNO}_{3}, \mathrm{HClO}_{4}$ и $\mathrm{HF}$. Химический состав ХЦ, w,\%: $\mathrm{SiO}_{2}$ 74.94; $\mathrm{Al}_{2} \mathrm{O}_{3} 11.92 ; \mathrm{TiO}_{2}$ 0.12; $\mathrm{Fe}_{2} \mathrm{O}_{3}$ 0.67; $\mathrm{CaO} 1.54 ; \mathrm{MgO} 0.18 ; \mathrm{Na}_{2} \mathrm{O}$ $1.72 ; \mathrm{K}_{2} \mathrm{O}$ 4.24. Химический состав ШЦ, w, \%: $\mathrm{SiO}_{2}$ 69.42; $\mathrm{Al}_{2} \mathrm{O}_{3}$ 13.06; $\mathrm{TiO}_{2}$ 0.34; $\mathrm{Fe}_{2} \mathrm{O}_{3}$ 2.14; $\mathrm{CaO} 3.00 ; \mathrm{MgO} 0.84 ; \mathrm{Na}_{2} \mathrm{O} 1.30 ; \mathrm{K}_{2} \mathrm{O}$ 2.95. Выявлено, что цеолитсодержащие породы отличаются составом катионно-обменного комплекса.

Воздушно-сухие цеолитсодержащие породы измельчали 2 мин в дробилке BOYD MK III (размер частиц $r<2.00$ мм), далее 3 мин подвергали механоактивации в дисковой вибрационной мельнице Essa LM2-P ( $<<0.50$ мм). Из полученного порошка высеивали высокодисперсную фракцию ( $\mathrm{r} \leq 0.30$ мкм).

Для синтеза полимерных композиционных материалов высокодисперсный порошок цеолитсодержащей породы пропитывали водным раствором ПВС ( $\mathrm{w}=4,6$ и 8 мас.\%) в различных соотношениях по массе $1: 2 ; 1: 1 ; 2: 1$ и тщательно перемешивали. Реакционные смеси оставляли на воздухе при $25^{\circ} \mathrm{C}$ на 72 часа для испарения рас- 
творителя. После механической гомогенизации получали композиционные материалы: ХЦ-ПВС ; $_{\text {w }}$ Ш-ПВС ${ }_{\mathrm{w}}$.

ИК-спектры регистрировали спектрометром SHIMADZU FTIR-8400S в области 4000-400 см-1 на таблетках, приготовленных по стандартной методике из порошка $\mathrm{KBr}$, содержащего 0.1-5.0 мас.\% композита. Степень кристалличности образцов $\mathrm{x}$ рассчитывали с погрешностью \pm 0.05 по отношению интенсивностей полос поглощения (п.п.) в ИК-спектрах образцов при 600 и $460 \mathrm{~cm}^{-1}$ :

$$
x=\frac{I_{600}}{I_{460}} .
$$

Относительные интенсивности п.п. рассчитывали, измеряя их длину до нулевой линии по отношению к длине п.п. с максимальной интенсивностью $\mathrm{v}_{\mathrm{s}}(\mathrm{Si}-\mathrm{O}-\mathrm{Si})=1040-1050 \mathrm{~cm}^{-1}$. Для расшифровки ИК-спектров использовали литературу [9].

Истинную плотность образцов определяли пикнометрическим методом с керосином $\left(\rho=0.817 г / \mathrm{cm}^{3}\right)$ в качестве рабочей жидкости, гигроскопическую влажность - по ГОСТ 28268-89, полную обменную емкость (ПОЕ) по $\mathrm{NH}_{4}{ }^{+}-$согласно отраслевой методике [10].

Кривые дифференциальной сканирующей калориметрии (ДСК), термогравиметрии (ТГ) и дифференциальной термогравиметрии (ДТГ) регистрировали синхронным термоанализатором STA 449F1 (фирма NETZSCH, Германия). Образцы массой $(17 \ldots 21 \pm 0.01)$ мг нагревали от 25 до $850^{\circ} \mathrm{C}$ в платиновых тиглях в динамической атмосфере аргона со скоростью $10^{\circ} \mathrm{C} /$ мин.

Асимметрию $S$ определяли как отношение отрезков, образованных проекциями восходящей ветви (в.в.) и нисходящей ветви (н.в.) ДТГ-кривой на нулевую линию [11]:

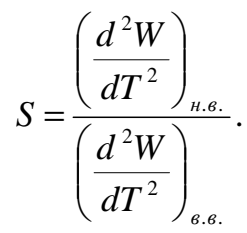
формуле:

Порядок реакции дегидратации $n$ вычисляли способом Киссинджера [12] по

$$
n=\sqrt{\frac{S}{0,63}} .
$$

Погрешность определения $\mathrm{S}$ и n по ДТГ-кривой составила \pm 0.05 . Кажущуюся энергию активации ( $E_{a}$, Дж/моль) процесса дегидратации в температурном интервале $80-140^{\circ} \mathrm{C}$ рассчитывали методом Бройдо [13] по уравнению:

$$
\ln \left[\ln \left(\frac{100}{100-\Delta m}\right)\right]=A-\left(E_{a} / R T\right)
$$

где $\Delta \mathrm{m}$ - потеря массы образца (в \%) при температуре $80 ; 100 ; 120 ; 140^{\circ} \mathrm{C} ; \mathrm{T}$ - температура, K; $\mathrm{R}=8.314$ Дж/(моль:К). Усредненные погрешности рассчитанных величин составили $\Delta \mathrm{E}_{\mathrm{a}} \approx \pm 3.00$ кДж/моль и $\Delta \mathrm{A} \approx \pm 1.00$ мин $^{-1}$.

Относительное изменение величины кажущейся энергии активации $\delta \mathrm{E}_{\mathrm{a}}$ в результате адсорбционного модифицирования цеолитсодержащих пород ПВС оценивали по формуле:

$$
\delta E_{a}=\frac{\left[E_{a}(Ц)-E_{a}\left(Ц-\Pi B C_{\omega}\right)\right] \cdot 100 \%}{E_{a}(Ц)} .
$$

где $\mathrm{E}_{\mathrm{a}}$ - кажущаяся энергия активации, кДж/моль; Ц = ХЦ; ШЦ. 


\section{Обсуждение результатов}

Известно, что на границе раздела между гидрофильным минеральным наполнителем и полимерной матрицей происходит обратимое разрушение напряженных связей с участием молекул воды [14]. Субботиной И.Р. предложен новый спектральный критерий реакционной способности адсорбированных молекул углеводородов на поверхностных кислотно-основных центрах цеолитного катализатора [15] - это понижение частот валентных колебаний, сопровождающиеся увеличением интенсивности соответствующих п.п. Образование адсорбционных поверхностных ком-

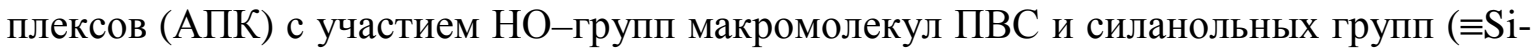
$\mathrm{OH})$ клиноптилолитового каркаса должно отражаться сдвигом и изменением относительных интенсивностей п.п. в ИК-спектрах образцов. Частоты при 3620, 3440, 2850$2950 \mathrm{~cm}^{-1}$ можно выбрать критериями оценки адсорбционного взаимодействия макромолекул и активных поверхностных центров минерального сорбента, так как указанные максимумы п.п. отвечают НО-группам цеолитного каркаса, молекул воды и $\mathrm{CH}_{2}$-группам. Для проверки этой гипотезы проведен анализ ИК-спектров образцов [9]. Результаты расчетов представлены в таблице 1.

Таблица 1. Частоты и относительные интенсивности некоторых полос поглощения, степень кристалличности

\begin{tabular}{|c|c|c|c|c|c|c|c|}
\hline Образцы & $\mathrm{v}, \mathrm{cm}^{-1}$ & $\mathrm{I} / \mathrm{I}_{0}$ & $\mathrm{x}$ & Образцы & $\mathrm{V}, \mathrm{cm}^{-1}$ & $\mathrm{I} / \mathrm{I}_{0}$ & $\mathrm{x}$ \\
\hline ХЦ & $\begin{array}{l}3611 \\
3431\end{array}$ & $\begin{array}{l}0.57 \\
0.59 \\
\end{array}$ & 0,69 & ШЦ & $\begin{array}{l}3622 \\
3431 \\
\end{array}$ & $\begin{array}{l}0.39 \\
0.44\end{array}$ & 0,65 \\
\hline ХЦ-ПВС ${ }_{4}(1: 2)$ & $\begin{array}{l}3626 \\
3416 \\
2945 \\
\end{array}$ & $\begin{array}{l}0.53 \\
0.61 \\
0.17 \\
\end{array}$ & 0,65 & ШЦ-ПВС 4 (1:2) & $\begin{array}{l}3624 \\
3418 \\
2943 \\
\end{array}$ & $\begin{array}{l}0.88 \\
0.98 \\
0.39 \\
\end{array}$ & 0,79 \\
\hline ХЦ-ПВС 4 (1:1) & $\begin{array}{l}3611 \\
3426 \\
2943 \\
\end{array}$ & $\begin{array}{l}0.85 \\
0.92 \\
0.30 \\
\end{array}$ & 0,78 & ШЦ-ПВС 4 (1:1) & $\begin{array}{l}3626 \\
3408 \\
2945 \\
\end{array}$ & $\begin{array}{l}0.53 \\
0.67 \\
0.19 \\
\end{array}$ & 0,74 \\
\hline ХЦ-ПВС ${ }_{4}(2: 1)$ & $\begin{array}{l}3622 \\
3441 \\
2974\end{array}$ & $\begin{array}{l}0.53 \\
0.54 \\
0.13\end{array}$ & 0,66 & ШЦ-ПВС 4 (2:1) & 3455 & 0.94 & 0,69 \\
\hline ХЦ-ПВС 6 (1:2) & $\begin{array}{l}3617 \\
3424 \\
2943 \\
\end{array}$ & $\begin{array}{l}0.49 \\
0.51 \\
0.13 \\
\end{array}$ & 0,63 & ШЦ-ПВС 6 (1:2) & $\begin{array}{l}3607 \\
3420 \\
2943 \\
\end{array}$ & $\begin{array}{l}0.55 \\
0.74 \\
0.26 \\
\end{array}$ & 0,66 \\
\hline ХЦ-ПВС 6 (1:1) & $\begin{array}{l}3609 \\
3418 \\
2943\end{array}$ & $\begin{array}{l}0.70 \\
0.76 \\
0.25 \\
\end{array}$ & 0,72 & ШЦ-ПВС 6 (1:1) & $\begin{array}{l}3628 \\
3408 \\
2947\end{array}$ & $\begin{array}{l}0.46 \\
0.53 \\
0.13 \\
\end{array}$ & 0,65 \\
\hline ХЦ-ПВС 6 (2:1) & $\begin{array}{l}3617 \\
3416 \\
2943\end{array}$ & $\begin{array}{l}0.84 \\
0.93 \\
0.29\end{array}$ & 0,78 & ШЦ-ПВС 6 (2:1) & $\begin{array}{l}3613 \\
3443 \\
2945\end{array}$ & $\begin{array}{l}0.40 \\
0.47 \\
0.08\end{array}$ & 0,65 \\
\hline ХЦ-ПВС ${ }_{8}(1: 2)$ & $\begin{array}{l}3617 \\
3391 \\
2943\end{array}$ & $\begin{array}{l}0.50 \\
0.58 \\
0.22\end{array}$ & 0,62 & ШЦ-ПВС ${ }_{8}(1: 2)$ & $\begin{array}{l}3628 \\
3416 \\
2943\end{array}$ & $\begin{array}{l}0.84 \\
1.00 \\
0.55\end{array}$ & 0,68 \\
\hline ХЦ-ПВС 8 (1:1) & $\begin{array}{l}3617 \\
3404 \\
2943\end{array}$ & $\begin{array}{l}0.88 \\
0.92 \\
0.32 \\
\end{array}$ & 0,77 & ШЦ-ПВС ${ }_{8}(1: 1)$ & $\begin{array}{l}3618 \\
3445 \\
2947\end{array}$ & $\begin{array}{l}0.49 \\
0.57 \\
0.14 \\
\end{array}$ & 0,68 \\
\hline ХЦ-ПВС ${ }_{8}(2: 1)$ & $\begin{array}{l}3619 \\
3418 \\
2943\end{array}$ & $\begin{array}{l}0.50 \\
0.53 \\
0.13\end{array}$ & 0,66 & ШЦ-ПВС 8 (2:1) & $\begin{array}{l}3628 \\
3431 \\
2947\end{array}$ & $\begin{array}{l}0.48 \\
0.52 \\
0.12\end{array}$ & 0,68 \\
\hline
\end{tabular}


Обнаружено, что относительные интенсивности п.п. композитов ХЦ-ПВС 4 $(1: 1)$, ХЦ-ПВС 6 (2:1) и ХЦ-ПВС 8 (1:1) имеют одинаковые значения, однако наблюдается увеличение смещения п.п. в области 3400-3431 см${ }^{-1}$ на величину 5, 15 и $27 \mathrm{~cm}^{-1}$ соответственно, по сравнению с п.П. в ИК-спектре ХЦ. При этом степень кристалличности указанных образцов увеличивается и составляет 0.78. Относительная интенсивность п.П. композитов ШЦ-ПВС $4-8$ зависит от концентрации водного раствора ПВС, что связано с развитой вторичной пористостью ШЦ и анизотропией поляризуемости различных колебаний в адсорбированных клиноптилолитом сегментах макромолекул. Следует отметить, что максимальные значения относительных интенсивностей п.П., характеризующих гидроксильные группы, наблюдаются в ИКспектрах образцов ШЦ-ПВС $(1: 2)$, ШЦ-ПВС ${ }_{4}(1: 2)$ и ШЦ-ПВС 6 (1:2). Степень кристалличности структуры данных композитов также увеличивается и принимает значения $0.68 ; 0.79$ и 0.66 . Изменения в ИК-спектрах полимерных композитов свидетельствуют об образовании АПК.

Ранее нами показано [8], что количественная оценка кинетических параметров уравнения С. Аррениуса, описывающих процесс дегидратации природных цеолитов в области температур 50-125 ${ }^{\circ}$, позволяет судить о степени дефектности его каркаса. Наличие дефектов и пор в структуре клиноптилолитов является благоприятным фактором для образования АПК. В этой связи, вычисляя кажущуюся энергию активации $\left(\mathrm{E}_{\mathrm{a}}\right)$ и предэкспоненциальный множитель (A), можно оценить адсорбционное взаимодействие цеолитной матрицы и ПВС, затрагивающее связи О-Н. Рассчитанные по кривым ТГ и ДТГ данные сведены в таблицу 2.

Таблица 2. Результаты анализа кривых дифференциальной сканирующей термогравиметрии и расчётов по кривым термогравиметрии и дифференциальной термогравиметрии

\begin{tabular}{|c|c|c|c|c|c|c|c|}
\hline \multirow[b]{2}{*}{ Образцы } & ДСК & \multicolumn{2}{|c|}{ ДТГ } & \multicolumn{4}{|c|}{$\mathrm{T} \Gamma$} \\
\hline & $\mathrm{t}_{\text {эндо }},{ }^{\circ} \mathrm{C}$ & $\begin{array}{l}\mathrm{t}_{\min }, \\
{ }^{\circ} \mathrm{C}\end{array}$ & $\begin{array}{l}\mathrm{S} ; \\
\mathrm{n}\end{array}$ & $\Delta \mathrm{m}_{\mathrm{T}^{*}}, \%$ & $\begin{array}{c}\mathrm{A}, \\
\text { мин }^{-1}\end{array}$ & $\begin{array}{c}\mathrm{E}_{\mathrm{a}}, \\
\text { кДж/моль }\end{array}$ & $\begin{array}{c}\delta \mathrm{E}_{\mathrm{a}}, \\
\%\end{array}$ \\
\hline 1 & 2 & 3 & 4 & 5 & 6 & 7 & 8 \\
\hline ХЦ & 143 & 144 & $0.57 ; 0.95$ & $\begin{array}{c}0.27 ; 0.59 ; 1.12 \\
1.81 ; 7.72\end{array}$ & 10.62 & 40.90 & 0 \\
\hline $\begin{array}{c}\text { ХЦ-ПВС } \\
(1: 1)\end{array}$ & $\begin{array}{l}142 ; \\
314\end{array}$ & 132 & $\begin{array}{l}0.77 \\
1.11\end{array}$ & $\begin{array}{c}0.30 ; 0.62 ; 1.17 \\
1.86 ; 10.00\end{array}$ & 9.77 & 38.88 & -5 \\
\hline $\begin{array}{c}\text { ХЦ-ПВС } \\
(1: 2)\end{array}$ & $\begin{array}{c}142 ; 287 \\
316\end{array}$ & 143 & $\begin{array}{l}0.90 \\
1.20\end{array}$ & $\begin{array}{c}0.28 ; 0.61 ; 1.15 \\
1.84 ; 10.30\end{array}$ & 10.03 & 39.90 & -2 \\
\hline $\begin{array}{c}\text { ХЦ-ПВС } 6 \\
(1: 1)\end{array}$ & $\begin{array}{l}135 \\
311\end{array}$ & 133 & $\begin{array}{l}0.69 \\
1.05\end{array}$ & $\begin{array}{c}0.29 ; 0.67 ; 1.26 \\
1.97 ; 12.17\end{array}$ & 10.08 & 40.38 & -1 \\
\hline $\begin{array}{c}\text { ХЦ-ПВС } 6 \\
(2: 1)\end{array}$ & $\begin{array}{l}137 \\
311\end{array}$ & 141 & $\begin{array}{l}1.00 \\
1.26\end{array}$ & $\begin{array}{c}0.31 ; 0.66 ; 1.23 \\
\quad 1.93 ; 11.53\end{array}$ & 9.62 & 38.72 & -5 \\
\hline $\begin{array}{c}\text { ХЦ-ПВС } \\
(1: 1)\end{array}$ & $\begin{array}{c}138 ; 276 ; \\
321\end{array}$ & 140 & $\begin{array}{c}0.80 \\
1.13\end{array}$ & $\begin{array}{c}0.33 ; 0.70 ; 1.27 \\
\quad 1.97 ; 11.46\end{array}$ & 9.39 & 37.83 & -8 \\
\hline $\begin{array}{c}\text { ХЦ-ПВС } \\
(1: 2)\end{array}$ & $\begin{array}{c}131 ; 314 ; \\
424\end{array}$ & 138 & $\begin{array}{l}1.04 \\
1.28\end{array}$ & $\begin{array}{c}0.47 ; 0.92 ; 1.53 \\
2.21 ; 15.18\end{array}$ & 7.70 & 32.64 & -20 \\
\hline ШЦ & $145 ; 270$ & 149 & $\begin{array}{c}0.92 \\
1.21\end{array}$ & $\begin{array}{c}0.33 ; 0.72 ; 1.34 \\
2.10 ; 11.19 \\
\end{array}$ & 9.93 & 39.34 & 0 \\
\hline $\begin{array}{c}\text { ШЦ-ПВС } \\
(1: 1)\end{array}$ & $\begin{array}{c}142 ; 287 ; \\
315\end{array}$ & 148 & $\begin{array}{c}0.96 \\
1.23\end{array}$ & $\begin{array}{c}0.30 ; 0.66 ; 1.25 \\
\quad 1.97 ; 13.16\end{array}$ & 9.77 & 39.64 & 1 \\
\hline $\begin{array}{c}\text { ШЦ-ПВС } 4 \\
(1: 2) \\
\end{array}$ & $\begin{array}{l}144 ; 262 ; \\
315 ; 414\end{array}$ & 142 & $\begin{array}{l}0.96 \\
1.23\end{array}$ & $\begin{array}{c}0.22 ; 0.56 ; 1.14 \\
1.85 ; 15.95\end{array}$ & 10.90 & 44.36 & 13 \\
\hline $\begin{array}{c}\text { ШЦ-ПВС } 6 \\
(1: 1)\end{array}$ & $\begin{array}{c}143 ; 289 ; \\
319\end{array}$ & 153 & $1.23 ; 1.39$ & $\begin{array}{c}0.25 ; 0.62 ; 1.21 \\
1.97 ; 13.90\end{array}$ & 10.75 & 43.15 & 10 \\
\hline
\end{tabular}




\begin{tabular}{|c|c|c|c|c|c|c|c|}
\hline 1 & 2 & 3 & 4 & 5 & 6 & 7 & 8 \\
\hline $\begin{array}{c}\text { ШЦ-ПВС } \\
(1: 2)\end{array}$ & $\begin{array}{c}140 ; \\
\text { Ш }\end{array}$ & 126 & $\begin{array}{c}0.66 ; \\
1.02\end{array}$ & $\begin{array}{c}0.23 ; 0.62 ; 1.23 ; \\
1.97 ; 17.46\end{array}$ & 10.94 & 44.55 & 13 \\
\hline $\begin{array}{c}\text { Ш-ПВС } \\
(1: 1)\end{array}$ & $143 ;$ & 127 & $\begin{array}{c}0.92 ; \\
1.21\end{array}$ & $\begin{array}{c}0.28 ; 0.65 ; 1.24 ; \\
1.97 ; 12.52\end{array}$ & 10.25 & 41.06 & 4 \\
\hline \begin{tabular}{|l} 
Ш-ПВС \\
$(1: 2)$
\end{tabular} & $\begin{array}{c}131 ; 228 ; \\
324 ; 434\end{array}$ & 136 & $\begin{array}{c}0.94 ; \\
1.22\end{array}$ & $\begin{array}{c}0.51 ; 1.01 ; 1.67 ; \\
5.61 ; 21.31\end{array}$ & 12.76 & 48.80 & 24 \\
\hline
\end{tabular}

$* \mathrm{~T}=353 ; 373 ; 393 ; 413 ; 1023 \mathrm{~K}$

Смещение ДТГ-экстремумов указывает на изменение энергоемкости процесса дегидратации воды с поверхности полимер-цеолитных композитов. Установлено, что процесс дегидратации природных цеолитов и композитов описывается кинетическим законом, близким к первому порядку (табл. 2). Анализ полученных в таблице 2 данных показал, что увеличение потери массы на ТГ-кривых композитов ШЦ$\Pi_{B} C_{8}(1: 2)$, ШЦ-ПВС 6 (1:2), ШЦ-ПВС 4 (1:2) сопровождается наибольшим увеличением значений кажущейся $\mathrm{E}_{\mathrm{a}}$, а для ХЦ-ПВС 8 (1:2), ХЦ-ПВС 6 (2:1), ХЦ-ПВС 4 (1:1) наблюдается наибольшее уменьшение значений кажущейся $\mathrm{E}_{\mathrm{a}}$. Вторичная пористость ШЦ и отсутствие в его составе стильбита обусловливают эффективную адсорбцию макромолекул ПВС на его поверхности, что отражается увеличением кажущейся $\mathrm{E}_{\mathrm{a}}$ процесса дегидратации. Следует отметить, что результаты ИКС и ТГ, представленные в таблицах 1 и 2 , хорошо согласуются между собой.

Изменение содержания сорбционной воды в исследуемых образцах должно находить подтверждение в измеренных величинах гигроскопической влажности (W). Анализ данных таблицы 3 показал различные значения гигроскопической влажности образцов, составляющие величину от 3.4 до 11.5\%. Выявлено, что образцы ШЦ$\Pi_{\mathrm{B}}$, в основном, имеют более высокие значения гигроскопической влажности, чем ХЦ-ПВС $\mathrm{w}_{\mathrm{w}}(\mathrm{w}=6 ; 8$ мас.\%), обратная закономерность наблюдается для композитов, полученных на основе природных цеолитов с использованием $4 \%$ водного раствора ПВС. Найдено, что наибольшее значение гигроскопической влажности имеют образцы: ШЦ-ПВС 6 (1:1), ХЦ-ПВС 4 (1:1), ХЦ-ПВС 6 (1:1), ШЦ-ПВС 8 (1:2), ШЦ$\Pi \mathrm{BC}_{4}(1: 2)$.

Таблица 3. Физические характеристики сорбентов: плотность, гигроскопическая влажность и полная обменная емкость по катиону аммония

\begin{tabular}{|c|c|c|c|c|c|c|c|}
\hline Образцы & $\begin{array}{c}\mathrm{d}, \\
\Gamma / \mathrm{cm}^{3}\end{array}$ & $\begin{array}{l}\mathrm{W}, \\
\%\end{array}$ & $\begin{array}{c}\text { ПОЕ, } \\
\text { мГ-ЭКв/Г }\end{array}$ & Образцы & $\begin{array}{c}\mathrm{d}, \\
\Gamma / \mathrm{cm}^{3}\end{array}$ & $\begin{array}{l}\mathrm{W}, \\
\%\end{array}$ & $\begin{array}{c}\text { ПОЕ, } \\
\text { мГ-эКВ/Г }\end{array}$ \\
\hline ЩЦ & 2.096 & 3.5 & 7.65 & ХЦ & 1.996 & 4.8 & 4.60 \\
\hline ШШЦ-ПВС 4 (1:2) & 1.873 & 7.0 & 6.89 & ХЦ-ПВС 4 (1:2) & 2.021 & 9.9 & 3.90 \\
\hline ШЦ-ПВС 4 (1:1) & 2.020 & 5.6 & 6.35 & ХЦ-ПВС 4 (1:1) & 2.067 & 10.7 & 3.85 \\
\hline ШЦ-ПВС 4 (2:1) & 2.015 & 5.8 & 6.20 & ХЦ-ПВС 4 (2:1) & 2.022 & 7.0 & 6.15 \\
\hline ШЦ-ПВС 6 (1:2) & 1.901 & 8.4 & 5.50 & ХЦ-ПВС 6 (1:2) & 1.997 & 3.8 & 1.91 \\
\hline ШЦ-ПВС 6 (1:1) & 1.975 & 11.5 & 5.67 & ХЦ-ПВС 6 (1:1) & 1.915 & 8.7 & 2.79 \\
\hline ШЦ-ПВС 6 (2:1) & 2.237 & 7.3 & 5.17 & ХЦ-ПВС 6 (2:1) & 1.976 & 3.9 & 4.10 \\
\hline ШЦ-ПВС 8 (1:2) & 2.341 & 8.2 & 3.09 & ХЦ-ПВС 8 (1:2) & 2.031 & 4.3 & 2.15 \\
\hline ШЦ-ПВС 8 (1:1) & 1.902 & 7.9 & 6.06 & ХЦ-ПВС 8 (1:1) & 1.902 & 4.2 & 3.26 \\
\hline ШЦ-ПВС 8 (2:1) & 1.798 & 5.3 & 8.24 & ХЦ-ПВС 8 (2:1) & 2.144 & 3.4 & 3.57 \\
\hline
\end{tabular}

В таблице 3 представлены экспериментально полученные значения ПОЕ исследуемых образцов по поглощенному $\mathrm{NH}_{4}{ }^{+}$с погрешностью \pm 0.28 мг-экв/г, В результате модифицирования клиноптилолитсодержащих пород макромолекулами 
ПВС величина ПОЕ снижается, что объясняется блокированием определенной доли пор клиноптилолита и гидрофобизацией его поверхности.

Истинная плотность образцов характеризует степень их упорядоченности. Обнаружено, что плотность композитов ШЦ-ПВС ${ }_{\mathrm{w}}$, практически во всех случаях, уменьшается по сравнению с исходным ШЦ, а у образцов ХЦ-ПВС ${ }_{\mathrm{w}}$, наоборот, увеличивается по сравнению с ХЦ (см. таблицу 3). Следовательно, имеет место как разупорядочение, так и упорядочение структуры композитов в результате адсорбционного модифицирования полимером природных цеолитов.

\section{Заключение}

Получены полимерные композиты с улучшенными влагоудерживающими свойствами на основе механоактивированной высокодисперсной фракции клиноптилолитсодержащих пород Холинского и Шивыртуйского месторождений и водных растворов 4, 6 и 8 мас.\% поливинилового спирта в соотношении (1:2; 1:1; 2:1). Образование адсорбционного поверхностного комплекса с участием силанольных групп клиноптилолита и гидроксильных групп поливинилового спирта подтверждено методами инфракрасной спектроскопии, дифференциальной сканирующей калориметрии и термогравиметрии. Критериями оценки адсорбционного взаимодействия выступали относительные интенсивности полос поглощения в области 3620, 3440, 2950-2850 $\mathrm{cm}^{-1}$ и параметры кинетического уравнения С. Аррениуса, описывающие дегидратацию образцов в температурном интервале $80-140^{\circ} \mathrm{C}$. Вторичная пористость природного цеолита Шивыртуйского месторождения способствует более эффективной модификации $8 \%$-ным водным раствором ПВС и лучшему влагоудержанию при соотношении исходных компонентов по массе 1:2. Модификация 4\%-ным водным раствором ПВС клиноптилолитсодержащей породы Холинского месторождения приводит к лучшему влагоудержанию композита при соотношении компонентов по мacce 1:1.

\section{Список литературы}

1. Перфильев А.В. Автореф. дисс. канд. хим. наук. Владивосток. 2012. 25 с.

2. Дабижа О.Н., Хатькова А.Н., Дербенева А.Н. // Сорбиионные и хроматографические проиессы. 2012. Т. 12. № 6. С. 860-866.

3. Гринев В.Г., Кудинова О.И., Ладыгина Т.А., Мешкова И.Н. и др. патент РФ. № 2284857. 2006.

4. Кац Э.М., Галкина Н.К., Серова И.Б. // Сорбиионные и хроматографические проueccbl. 2012. T. 12. № 3. С. 363-369.

5. Хатькова А.Н., Дабижа О.Н., Дербенева Т.В., Бурнашова Н.Н. // ГИАБ. 2011. № 10. С. 278-283.

6. Глухих В.В., Шкуро А.Е., Гуда Т.А., Стоянов О.В. // Вестник Казанского технологического университета. 2012. Т. 15. № 9. C. $75-82$.

7. Солдатенко Е.М. Дисс. канд. хим. наук. Саратов. 2015. $123 \mathrm{c}$.
8. Дабижа О.Н., Дербенева Т.В., Хатькова А.Н., Филенко Р.А. и др. // Химия в интереcax устойчивого развития. 2016. Т. 24. № 2. C. 193-201.

9. Брек Д. Цеолитовые молекулярные сиma. М. Мир. 1976.781 c.

10. Богданова В.И., Белицкий И.А., Предеина Л.М., Галай Г.И. и др. Определение ионообменной емкости цеолитсодержащей породы по поглощенному аммонию: отраслевая методика. Новосибирск. 1993. 21 с.

11. Ферапонтов Ю.А., Путин С.Б., Ферапонтова Л.Л., Путин П.Ю. // Вестник ТГТУ. 2009. T. 15. № 4. C. 826-835.

12. Kissinger H.E. // Analyt. Chem. 1957. Vol. 29. p. 1702.

13. Берштейн В.А. Егоров В.М. Дифференциальная сканирующая калориметрия в физикохимии полимеров. Ленинград. Химия. 1990. $256 \mathrm{c}$. 
14. Дабижа О.Н. Дисс. канд. хим. наук. Санкт-Петербург. 2010. 113 с.

\section{References}

1. Perfiliev A.V., Avtoref. Diss. cand. chem. Nauk, Vladivostok, 2012, 25 p.

2. Dabizha O.N., Khat'kova A.N., Derbeneva T.V., Sorbtsionnye i khromatograficheskie protsessy, 2012, Vol. 12, No 6, pp. 860-866.

3. Grinev V.G., Kudinova O.I., Ladygina T.A., Meshkova I.N. et al., patent RF, No 2284857, 2006.

4. Kats E.M., Galkina N.K., Serova I.B., Sorbtsionnye i khromatograficheskie protsessy, 2012, Vol. 12, No 3, pp. 363-369.

5. Khat'kova A.N., Dabizha O.N., Derbeneva T.V., Burnashova N.N., GIAB, 2011, No 10, pp. 278-283.

6. Glukhikh V.V., Shkuro A.E., Guda T.A., Stoyanov O.V., Bulletin of Kazan Technological University, 2012, Vol. 15, No 9, pp. 75-82.

7. Soldatenko E.M., Diss. cand. chem. Nauk, Saratov, 2015, 123 p.

8. Dabizha O.N., Derbeneva T.V., Khat'kova A.N., Filenko R.A. et al., Chemistry for Sus-

Дабижа Ольга Николаевна - доцент, к.х.н., доцент кафедры химии Забайкальского государственного университета, с.н.с. Забайкальского института железнодорожного транспорта, Чита, тел. (3022)41-71-22

Хатькова Алиса Николаевна - профессор, д.т.н., профессор кафедры химии Забайкальского государственного университета, Чита

Рябова Наталия Викторовна - магистрант Забайкальского государственного университета, Чита

Филенко Роман Андреевич - младший научный сотрудник лаборатории геохимии и рудогенеза Института природных ресурсов, экологии и криологии СО РАН, Чита
15. Субботина И.Р. Автореф. дисс. д.Х.н. M. $2010.52 \mathrm{c}$.

tainable Development, 2016, Vol. 24, No 2, pp. 193-201.

9. Brek D., Ceolitovye molekulyarnye sita, M., Mir, 1976, $781 \mathrm{p}$.

10. Bogdanova V.I., Belitsky I.A., Predeina L.M., Galay G.I. et al., Opredelenie ionoobmennoj emkosti ceolitsoderzhashchej porody po pogloshchennomu ammoniyu: otraslevaya metodika, Novosibirsk, 1993, 21 p.

11. Ferapontov Yu.A., Putin S.B., Ferapontova L.L., Putin P.Yu., Bulletin of TSTU, 2009, Vol. 15, No 4, pp. 826-835.

12. Kissinger H.E., Analyt. Chem, 1957, Vol. 29 , p. 1702.

13. Bershtein V.A. Egorov V.M. Differencial'naya skaniruyushchaya kalorimetriya $\mathrm{v}$ fizikohimii polimerov. Leningrad, Khimia, 1990, $256 \mathrm{p}$.

14. Dabizha O.N. Diss. cand. chem. nauk. St. Petersburg, 2010, $113 \mathrm{p}$.

15. Subbotina I.R. Avtoref. Diss. doc. chem. nauk. Moscow, 2010, 52 p.

Dabizha Olga N. - associate professor, Ph.D. (chemistry), associate professor of the department of chemistry of Transbaikal State University, senior scientist, Transbaikal Institute of Railway Transport, Chita, e-mail: dabiga75@mail.ru

Khat'kova Alisa N. - professor, doctor of technical sciences, professor of the department of chemistry of Transbaikal State University, Chita

Ryabova Natalia V. - graduate student of Transbaikal State University, Chita

Filenko Roman A. - junior researcher of the laboratory of geochemistry and ore genesis of Institute of Natural Resources, Ecology and Cryology Siberian Division of the Russian Academy of Sciences, Chita 